JOPPAS: Journal of Public Policy and Administration Silampari

Volume 1, Nomor 1, Desember 2019

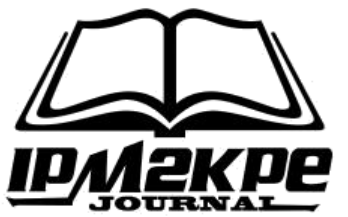

\title{
STRATEGI DINAS PARIWISATA \\ DALAM MENUNJANG PENDAPATAN ASLI DAERAH (PAD)
}

\author{
Siti Meliyani \\ Universitas Muhammadiyah Sukabumi \\ melianisiti606@gmail.com
}

\begin{abstract}
ABSTRAK
Tujuan penelitian ini untuk mengetahui faktor-faktor yang mempengaruhi keberhasilan Dinas Pariwisata dalam Menunjang Pendapatan Asli Daerah (PAD) di Kabupaten Sukabumi dari PAD Bumi Perkemahan Cinumpang dengan menggunakan Dess dan Miller dimensi yang pertama : 1) sasaran-sasaran, 2) kebijakan, 3) rencana-rencana. Penelitian ini menggunakan metode kualitatif dengan informan 6 orang dan teknik pengumpulan data observasi, wawancara, dokumentasi. Prosedur analisis data menggunakan model yang dikemukakan oleh Bogdan. Hasil penelitian menunjukan bahwa strategi Dinas Pariwisata dalam menunjang Pendapatan Asli Daerah (PAD) sudah berjalan baik, ditandai dengan target pendapatan asli daerah yang ada di Bumi Perkemahan Cinumpang sudah meningkat. Sasaran dan kebijakan, rencana-rencana, bahwa pada masing-masing dimensi sudah dikatakan baik dalam strateginya. Sedangkan faktor penghambatnya adalah kurangnya dukungan dari masyarakat tentang pentingnya menjaga dan suatu obyek wisata. Simpulan, strategi Dinas Pariwisata dalam Menunjang Pendapatan Asli Daerah (PAD) sudah berjalan baik.
\end{abstract}

Kata Kunci : Strategi, Pendapatan Asli Daerah.

\begin{abstract}
The purpose of this study was to determine the factors that influence the success of the Tourism Office in Supporting Local Original Revenue (PAD) in Sukabumi Regency from PAD Bumi Perkumpang Cinumpang using the first dimension Dess and Miller: (1) Targets (2) Policies (3) ) Plans. This study used a qualitative method with 6 informants and data collection techniques of observation, interviews, documentation. Data analysis procedures using the model proposed by Bogdan. The results showed that the strategy of the Department of Tourism in Supporting Regional Original Revenue (PAD) has been going well, marked by the target of local original income in the Cinumpang Campsite has increased. Targets and policies, plans, that in each dimension have been said to be good in their strategies. While the inhibiting factor is the lack of support from the public about the importance of maintaining and a tourist attraction. In conclusion, the strategy of the Department of Tourism in Supporting Local Revenue (PAD) has been going well.
\end{abstract}

Keywords: Strategy, Regional Original Revenue. 


\section{PENDAHULUAN}

Obyek wisata merupakan segala sesuatu yang ada di daerah tujuan wisata, oleh karena itu pariwisata sangat di mungkinkan karena ketersediaan berbagai potensi pariwisata dalam bentuk regulasi. Salah satunya adalah obyek wisata yang ada di Kabupaten Sukabumi yaitu Bumi Perkemahan Cinumpang Kabupaten Sukabumi. Menurut salah satu koordinator pariwisata Bumi Perkemahan Cinumpang Kabupaten Sukabumi bahwa sifat dari pariwisata itu sendiri yaitu dinamis, dimana suatu saat akan muncul titik kejenuhan atau kebosanan bagi wisatawan untuk menikmati kondisi yang sudah ada, dan itu sangat berpengaruh pada tingkat kunjungan wisatawan ke suatu obyek wisata yang pastinya berdampak langsung pada Pendapatan Asli Daerah dari sektor pariwisata.

Pendapatan Asli Daerah (PAD) merupakan gambaran potensi keuangan yang ada di daerah pada umumnya mengacu pada unsur pajak daerah dan retribusi daerah (Adrian, 2009). Dengan pendapatan asli daerah dari sektor retribusi, maka daerah akan mampu menggali potensi sumber daya alam yang ada berupa pada sektor pariwisata. Pemerintahan menyadari bahwa sektor dari pariwisata bukanlah sektor penyambung terbesar dalam pendapatan asli daerah, akan tetapi berpotensi dalam meningkatkan Pendapatan Asli Daerah (PAD).

Penelitian ini dari Yamin Analisis Strategi pengembangan Pariwisata Terhadap Peningkatan Pendapatan Asli Daerah Kabupaten Bangka 2005 Kurang memaksimalkan penerapan kegiatan pengembangan kepariwisataan karena masalah komunikasi, sumber daya, sikap pelaksana kebijakan dan Struktur birokrasi. Penelitian ini dari Damayanti Strategi pengembangan kawasan wisata kepulauan Banda kurangnya sumber daya manusia di kawasan Wisata Kepulauan Banda. Penelitian ini dengan penelitian terdahulu adalah : penelitian terdahulu berfokus kepada Strategi Dinas Pariwisata Dalam Menunjang Pendapatan Asli Daerah Di Kabupaten Sukabumi (Studi Kasus Bumi Perkemahan Cinumpang) Untuk lebih meningkatkan wisatawan, dan masih kurang perawatan lokasi.

\section{KAJIAN TEORI}

Adapun Strategi yang dikemukakan oleh Dess dan Miller dalam buku Saladin (2003). Strategi efektif mengandung unsur penting yaitu :

1. Sasaran-sasaran. Tujuan merupakan hasil yang ingin di capai oleh suatu instansi. Sasaran merupakan salah satu dimensi yang dapat menciptakan sebuah strategi karena penetapan tujuan yang sangat berkaitan langsung dengan strategi yang akan digunakan oleh sebuah instansi dalam pencapaian tujuanya, dimana ketika tujuan sudah ditetapkan kita dapat mengetahui startegi yang akan digunakan.

2. Kebijakan. Kebijakan rangkaian keputusan yang membimbing dan membatasi tindakan yang dilakukan. Kebijkan dibuat untuk menetapkan arah suatu tujuan yang ditetapkan sehingga pembuatan kebijakan lebih memudahkan untuk mengarahkan suatu instansi dalam merupakan suatu strategi.

3. Rencana-rencana. Rencana merupakan urutan tindakan yang akan dilakukan dalam pencapaian tujuan yang ditetapkan. Rencana yang akan mengatur segala tindakan 
yang dilakukan sehingga strategi yang diterapkan telah dapat terlaksana secara maksimal.

Selanjutnya. Dess dan Miller dalam buku Saladin (2003), membagi hirarki atau tingkatan dari sasaran tersebut menjadi :

1. Visi (vision) : apa yang akan dilakukan organisai perusahaan visi merupakan kerangka acuan dan presfektif sebagai satu kesatuan yang tercermin dalam kegiatan nyata.

2. Misi (mission) : banyaknya batasan sasaran yang akan dicapai. Misi merupakan tugas dan prinsip pokok dalam mewujudkan visi.

3. Tujuan-tujuan (objectives) : tujuan yang lebih spesifik ingin dicapai. Secara ideal berarti kita harus mencari suatu kepastian akhir.

Kebijakan (policies) : merupakan garis pedoman untuk bertindak, bagaimana sebuah organisasi mencapai sasaran-sasaran tersebut. Rencana-rencana (plans) : suatu pertanyaan dari tindakan seseorang manajer organisasi terhadap apa yang diharapkan akan terjadi.Strategi yang direalisasikan (realized strategic) : merupakan apa yang dicapai atau apa yang telah terwujudkan (Gamal, 2004). Strategi yang original itu sering mengalami perubahan dalam keseluruhan implementasinya, sesuai dengan peluang dan ancaman yang dihadapi. Strategi yang sebenarnya terwujudkan selalu lebih banyak atau sedikit dari pada strategi yang di kehendaki. Untuk memperoleh gambaran yang lebih lengkap lagi, elemen strategi induk itu secara keseluruhan adalah sebagai berikut; a) visi, b) misi, c) tujuan, d) sasaran-sasaran, e) strategi, f) kebijakan (Siahan, 2010)

\section{METODE PENELITIAN}

Dalam penelitian kualitatif berangkat dari kasus tertentu yang ada pada situasi sosial tertentu dan hasil kajiannya tidak akan diberlakukanya pada populasi, akan tetapi ditransferkan ketempat lain pada situasi sosial dalam kasus yang dipelajari, dalam penelitian kualitatif ini sampel tidak disebut sebagai responden melainkan narasumber, partisipan, dan informan. Pada penelitian ini yang menjadi indikator penelitian adalah Strategi Dinas Pariwisata Dalam Menunjang Pendapatan Asli Daerah Di Kabupaten Sukabumi. Strategi merupakan suatu pelaksanaan dari sebuah rencana yang sudah dibuat secara matang dan terperinci. Untuk mengkaji suatu strategi kebijakan publik dengan baik maka perlu diketahui faktor-faktor dan variabel yang mempengaruhinya.

Teknik pengumpulan data merupakan langkah yang strategs didalam penelitian. Tujuan dari penelitian ini sendiri adalah mendapatkan data. Dalam penelitian kualitatif, pengumpulan data dari penelitian ini adalah mendapatkan data. Dalam penelitian kualitatif, pengumpulan data dilakukan pada natural setting (kondisi yang alamiah), sumber data primer, teknik pengumpulan data lebih banyak obeservasi berperan serta, wawancara mendalam, dan dokumentasi. Teknik pengembangan data yang digunakan dalam penelitian ini adalah triangulasi. Triangulasi dalam pengujian kreadibilitas diartikan sebagai pengecekan data dari berbagai sumber dengan berbagai cara dan berbagai waktu.

\section{HASIL PENELITIAN}

\section{Sasaran-sasaran (goals)}

Menurut Dess dan Miller dalam Saladin sasaran-sasaran merupakan apa yang ingin dicapai oleh suatu instansi. Sasaran merupakan salah satu dimensi yang dapat menciptakan sebuah strategi karena penetapan tujuan yang sangat berkaitan langsung dengan strategi yang akan digunakan oleh sebuah instansi dalam pencapaian tujuanya, 
dimana ketika tujuan sudah ditetapkan kita dapat mengetahui strategi yang di gunakan. Berdasarkan hasil wawancara pada tanggal 26 juni 2019 dengan informan 1 yaitu:

"Tahun ini dilaksanakan perbaikan sarana dan prasarananya, karena itu sudah tugas pariwisata, kemarin kita kan fokusnya dibeberapa titik dulu supaya hasilnya lebih bagus, seperti Pantai Geopark dulu dan tahun ini Bumi Perkemahan Cinumpang, penataan obyek wisata jalan menuju tembusan ke gunung salak, karena memang lokasinya tidak jauh beda dari cinumpang menuju ke situ gunung, kita juga dalam pembangunan tersebut tetap koordinasi dengan warga setempat dan camat".

Berdasarkan hasil wawancara pada tanggal 26 juni 2019 dengan informan 2 yaitu:

“ Untuk Bumi Perkemahan Cinumpang itu kebanyakan wisatawan dari Nusantara, untuk hari sabtu dan minggu itu kebanyakan wisatawan yang berkemah di Bumi Perkemahan Cinumpang ada juga untuk hari-hari biasanya wisatawan yang datang tetapi tidak banyak seperti hari sabtu dan minggu, untuk sarana dan prasarana di Bumi Perkemahan Cinumpang ini memang kurang lengkap, untuk biaya tiket masuk ke Bumi Perkemahan Cinumpang Perorang RP.3.500, pejalan kaki RP. 3.000, Motor Rp.8.000, Mobil Rp.20.000 untuk berkemah sewa tempat 10.000 dan untuk perminggunya bisa mencapai 200 orang, untuk kunjungan yang terjaring masuk ke PAD dan tidak terjaring tidak masuk ke PAD".

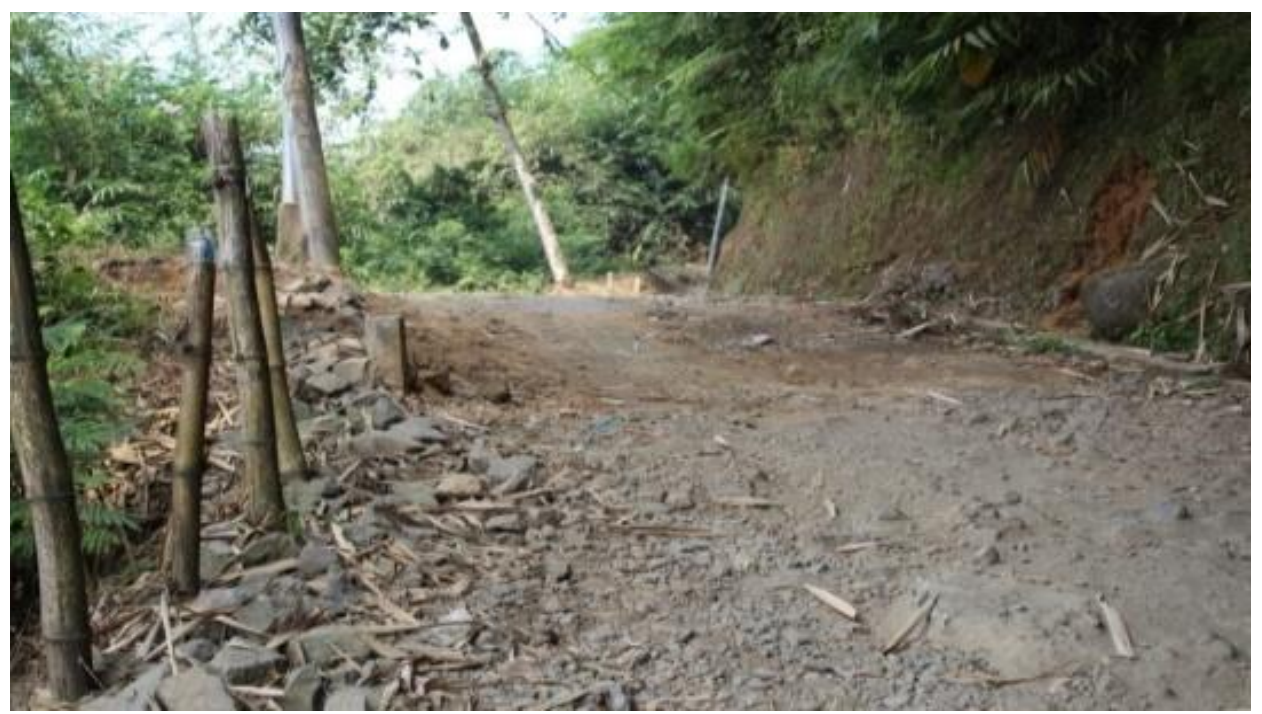

Sumber: penelitian,2019

Gambar 1. Akses Jalan Cinumpang 


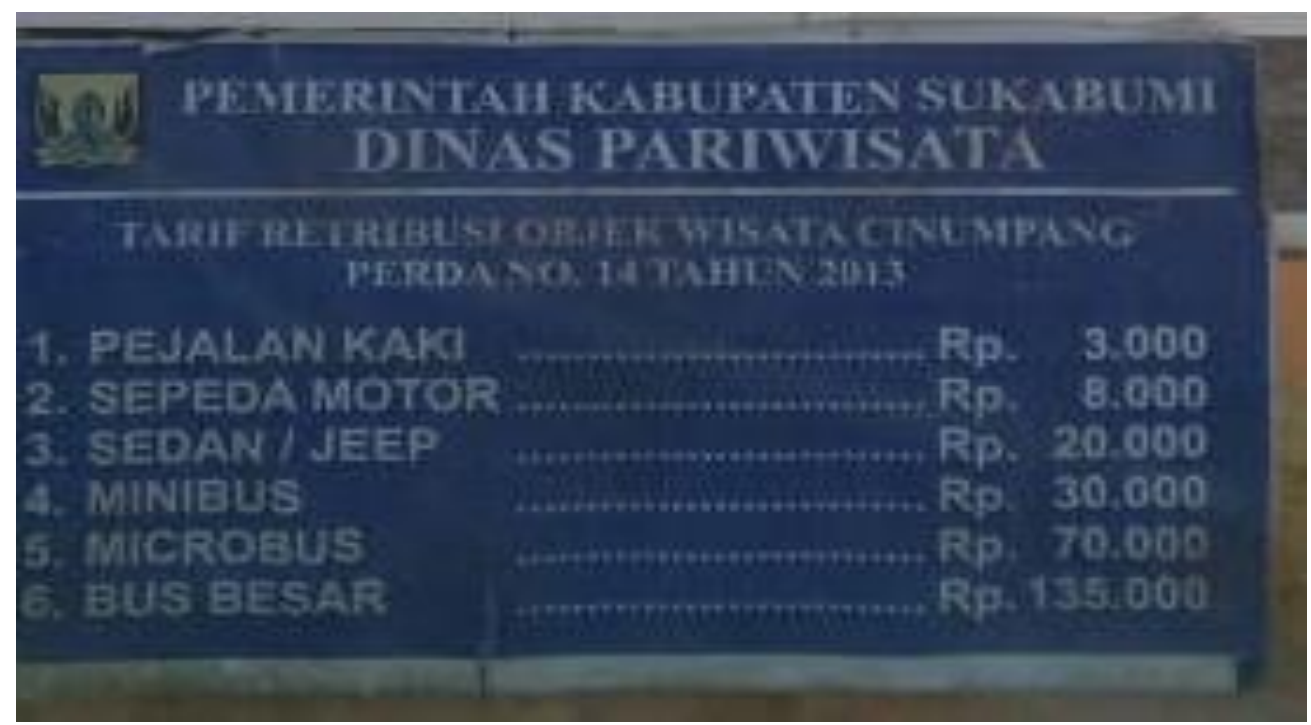

Sumber: penelitian,2019

\section{Gambar 2 Tarif Retribusi Cinumpang}

Dari gambar tersebut dapat dilihat bahwa perbedaan yang sangat jauh dalam akses menuju tempat wisata geopark ciletuh dan akses menuju bumi perkemahan cinumpang. Hasil yang ingin di capai oleh Dinas Pariwisata Kabupaten Sukabumi yaitu penataan atau pembangunan Geopark Ciletuh telah diselesaikan pada tahun 2019. Setelah itu pihak Dinas Pariwisata Kabupaten Sukabumi akan fokus dalam membangun penataan Obyek Wisata Bumi Perkemahan Cinumpang seperti akses jalan menuju ke lokasi Bumi Perkemahan Cinumpang dan penataan yang lainya akan segera di perbaiki oleh pihak Dinas Pariwisata Kabupaten Sukabumi.

\section{Kebijakan}

Kebijakan menurut Dess dan Miller dalam Saladin merupakan garis pedoman untuk bertindak, bagaimana sebuah organisasi mengacu sasaran-sasaran tersebut. Kebijakan juga dapat diartikan sebagai rangkaian keputusan membimbing dan membatasi tindakan yang dilakukan. Kebijakan dibuat untuk menetapkan arah suatu tujuan yang ditetapkan sehingga pembuatan kebijakan lebih memerlukan untuk mengarahkan suatu organisasi atau instansi dalam penerapan sasaran strategi. Berdasarkan hasil wawancara 24 juni 2019 informan 1 yaitu :

"Yang menjadi keunggulan Kabupaten Sukabumi itu adalah dalam bidang pariwisata dalam Visi-Misi Kabupaten Sukabumi dan Bupati Sukabumi, untuk meraih minat dan mencerdaskan masyarakat Kabupaten Sukabumi Dinas Pariwisata mengadakan dan memudahkan minat investor itu datang untuk memudahkan investor Dinas Pariwisata selalu mengadakan menjemput bola dan mengadakan MOU dengan para investor bagaimana hak dan kewajiban mereka dan kabupaten sukabumi untuk menguntungkan bersama dan sifatnya multi efek dan harus menjaga kemasyarakat sekitar jangan mentang-mentang habis langkah untuk point pertama yang di pegang itu mensejahterakan masyarakat." 


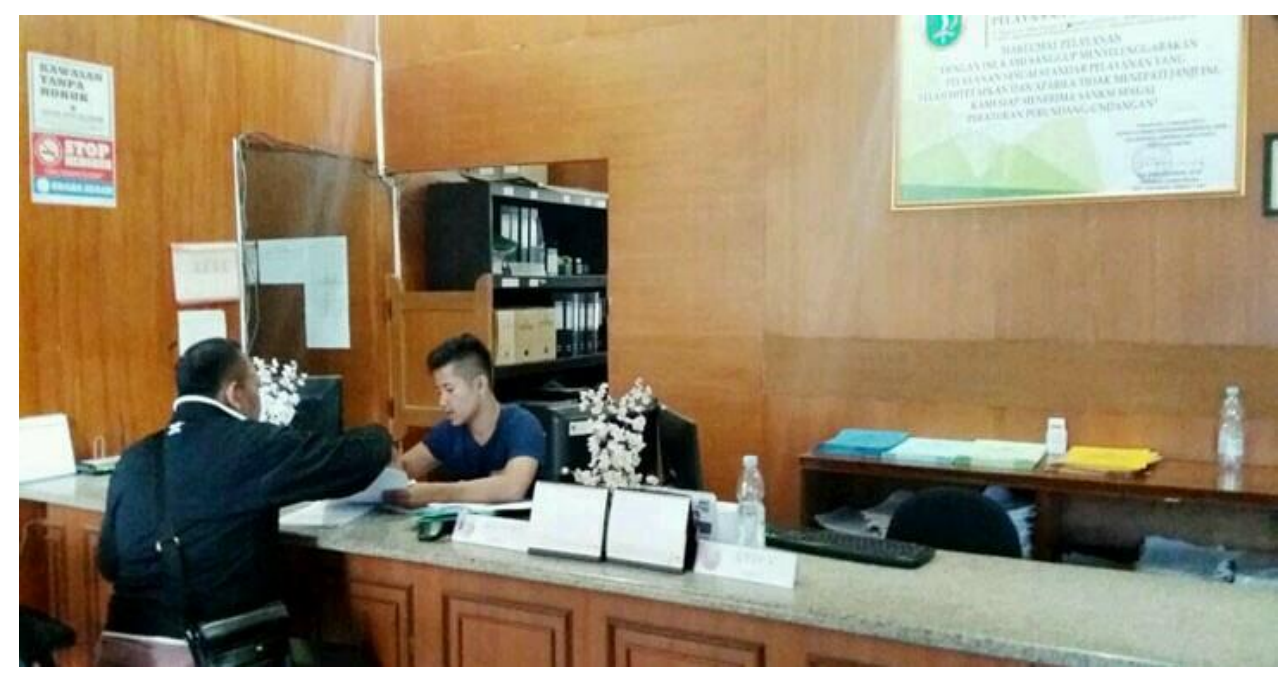

Sumber: Penelitian,2019

\section{Gambar 3 Pegawai Dinas Pariwisata Melakukan MoU}

Kebijakan adalah rangkaian keputusan yang membimbing dan membatasi tindakan yang dilakukan. Adapun kebijakan Dinas Pariwisata Kabupaten Sukabumi dalam pembangunan kepariwisataan adalah :

1. Program dan kegiatan peningkatan kualitas sumber daya manusia (SDM) aparatur, masyarakat dan pengaku kepentingan (Stakeholder).

2. Program dan kegiatan pengembangan industri budaya dan pariwisata yang berdaya saing.

3. Program dan kegiatan pengembangan Citra Destinasi.

4. Program dan kegiatan peningkatan peran serta masyarakat dalam pembangunan pariwisata.

Sedangkan tanggapan dari informan 2 yaitu :

"Untuk wisatawan yang datang selalu ditanyakan E-KTP dan kalau ada buku nikah bagi yang menginap ke Bumi Perkemahan Cinumpang ini kebanyakan wisatawan yang berkunjung kesini itu wisatawan Nusantara dan pada waktu itu juga ada wisatawan yang datang dari luar Jawa Barat dan itupun tidak banyak sekitar 30 orang berkemah ke wisata Bumi Perkemahan Cinumpang."

Tanggapan yang sama dari informan $3 \& 4$ menyatakan bahwa kebijakankebijakan yang telah dijalankan oleh Pemerintah dalam hal ini Dinas Pariwisata Kabupaten Sukabumi dalam hal peningkatan obyek wisata di Kabupaten Sukabumi khususnya Kecamatan Kadudampit keseluruhan belum berjalan sesuai dengan rencana. Masih kurangnya media pemasaran untuk meningkatkan pariwisata yang berdaya saing.

\section{Rencana-rencana (plans)}

Rencana menurut teori Dess dan Miller dalam Saladin merupakan suatu pertanyaan dari tindakan seorang manajer organisasi terhadap apa yang diharapkan akan terjadi. Rencana-rencana merupakan urutan tindakan yang akan dilakukan dalam mencapai tujuan yang akan ditetapkan yaitu rencana untuk mengatur segala tindakantindakan yang akan dilakukan. Adapun Rencana Pengembangan Pemasaran Pariwisata 
yang ditetapkan oleh Komisioner Dinas Pariwisata Kabupaten Sukabumi, dengan kegiatan pokok yaitu :

1. Analisa pasar untuk promosi dan pemasaran obyek pariwisata.

2. Peningkatan pemanfaatan teknologi informasi dalam pemasaran pariwisata.

3. Pengembangan jaringan promosi pariwisata.

4. Koordinasi dengan sektor pendukung pariwisata.

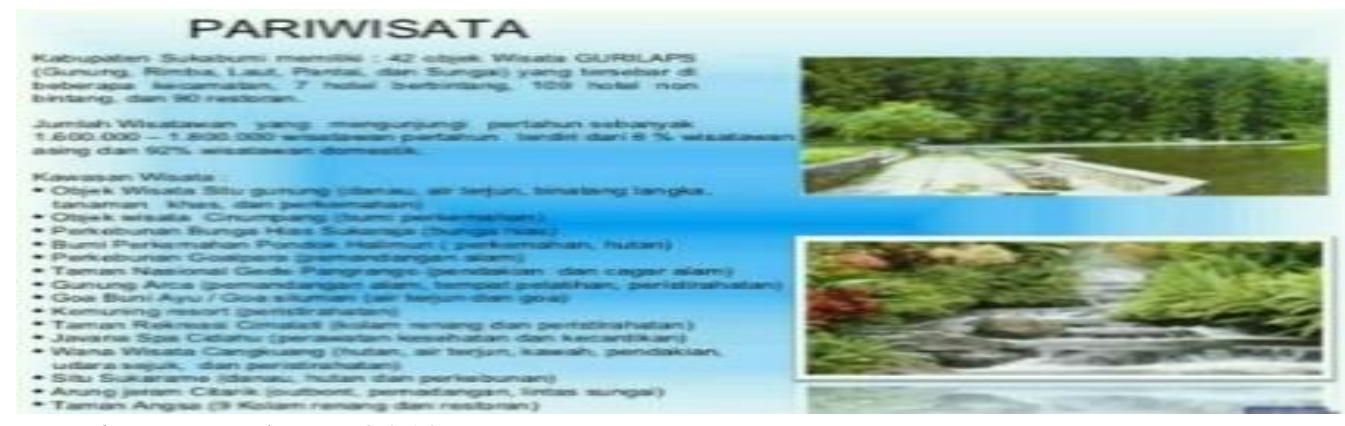

Sumber :Penelitian, 2019

Gambar 4 Spanduk Dinas Pariwisata

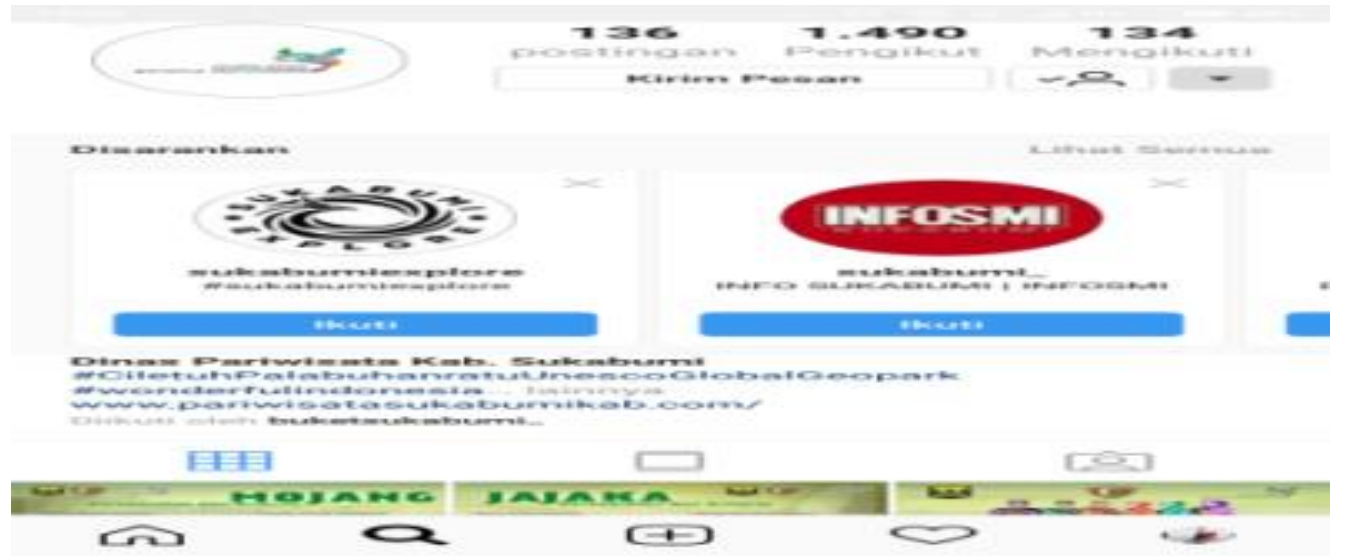

Sumber : Penelitian,2019

Gambar 5 Instagram Dinas Pariwisata

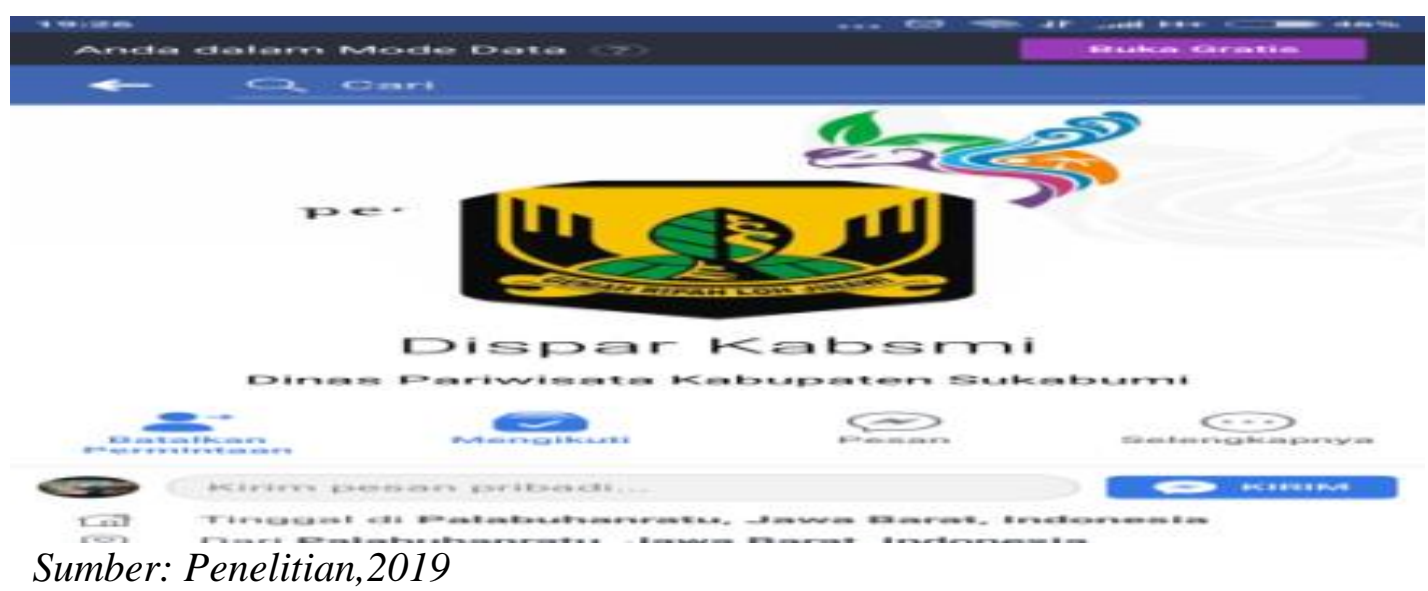

Gambar 6 Facebook Dinas Pariwisata 
Informan 3 juga mempunyai peran yang besar dalam meningkatkan sebuah kawasan obyek wisata yang membuat kawasan wisata tersebut dapat diketahui oleh para wisatawan salah satunya dengan cara mempromosikan mengatakan.

"Yang namanya pemasaran masih ada seperti pembangunan prinsip dari dari semua pembangunan dengan adanya aturan-turan pemerintah yang lainya menyesuaikan ke yang lebih tinggi seperti perda, untuk pengelolaan obyek wisata secara keseluruhan dalam kesejahteraan masyarakat pengelolaan pariwisata itu bukan mengacu dalam hal bisnis dan dengan adanya obyek wisata untuk penduduk wisata untuk memanfaatkan peluang-peluang usaha atau jasa-jasa cendramata hasil karya masyarakat sekitar dengan adanya multi efek".

Menurut teori Dess dan Miller dalam buku Saladin rencana merupakan urutan tindakan yang akan dilakukan dalam pencapaian tujuan yang ditetapkan, rencana yang akan mengatur segala tindakan yang dilakukan sehingga strategi yang diterapkan telah dapat terlaksana secara maksimal. Dinas Pariwisata telah mempromosikan kepada masyarakat mengenai obyek wisata Bumi Perkemahan Cinumpang dengan tujuan untuk lebih meningkatkan pencapaian wisatawan yang berkunjung ke Bumi Perkemahan Cinumpang agar tidak terjadi penurunan Pendapatan Asli Daerah. Dengan demikian peneliti intrepretasikan bahwa rencana Dinas Pariwisata dengan pihak-pihak terkait yang ada di dalam Perda No.105 Tahun 2018 sudah baik dan sudah berjalan dengan semestinya. Dan pada dimensi ini peneliti pun ingin mengetahui bagaimana komunikasi yang telah dijalankan oleh Dinas Pariwisata dengan masyarakat tentang peningkatan wisatawan ke Bumi Perkemahan Cinumpang.

\section{PEMBAHASAN}

Untuk meningkatkan wisatawan yang berkunjung dan meningkatkan pendapatan asli daerah tentunya harus diikuti dengan sarana dan prasarana yang memadai dan gencarnya promosi yang dilakukan. Namun dalam hal pemasaran pariwisata masih kurang, karena belum adanya fokus dalam promosi Bumi Perkemahan Cinumpang. Adapun Strategi yang dikemukakan oleh Dess dan Miller dalam buku Saladin (2003). Strategi efektif mengandung unsur penting yaitu :

1. Sasaran-sasaran. Tujuan merupakan hasil yang ingin di capai oleh suatu instansi. Sasaran merupakan salah satu dimensi yang dapat menciptakan sebuah strategi karena penetapan tujuan yang sangat berkaitan langsung dengan strategi yang akan digunakan oleh sebuah instansi dalam pencapaian tujuanya, dimana ketika tujuan sudah ditetapkan kita dapat mengetahui startegi yang akan digunakan.

2. Kebijakan. Kebijakan rangkaian keputusan yang membimbing dan membatasi tindakan yang dilakukan. Kebijkan dibuat untuk menetapkan arah suatu tujuan yang ditetapkan sehingga pembuatan kebijakan lebih memudahkan untuk mengarahkan suatu instansi dalam merupakan suatu strategi.

3. Rencana-rencana. Rencana merupakan urutan tindakan yang akan dilakukan dalam pencapaian tujuan yang ditetapkan. Rencana yang akan mengatur segala tindakan yang dilakukan sehingga strategi yang diterapkan telah dapat terlaksana secara maksimal.

Selanjutnya. Dess dan Miller dalam buku Saladin (2003), membagi hirarki atau tingkatan dari sasaran tersebut menjadi : 
1. Visi (vision) : apa yang akan dilakukan organisai perusahaan visi merupakan kerangka acuan dan presfektif sebagai satu kesatuan yang tercermin dalam kegiatan nyata.

2. Misi (mission) : banyaknya batasan sasaran yang akan dicapai. Misi merupakan tugas dan prinsip pokok dalam mewujudkan visi.

3. Tujuan-tujuan (objectives) : tujuan yang lebih spesifik ingin dicapai. Secara ideal berarti kita harus mencari suatu kepastian akhir.

Kebijakan (policies) : merupakan garis pedoman untuk bertindak, bagaimana sebuah organisasi mencapai sasaran-sasaran tersebut. Rencana-rencana (plans) : suatu pertanyaan dari tindakan seseorang manajer organisasi terhadap apa yang diharapkan akan terjadi.Strategi yang direalisasikan (realized strategic) : merupakan apa yang dicapai atau apa yang telah terwujudkan. Strategi yang original itu sering mengalami perubahan dalam keseluruhan implementasinya, sesuai dengan peluang dan ancaman yang dihadapi. Strategi yang sebenarnya terwujudkan selalu lebih banyak atau sedikit dari pada strategi yang di kehendaki (Diarta, 2009). Untuk memperoleh gambaran yang lebih lengkap lagi, elemen strategi induk itu secara keseluruhan adalah sebagai berikut; a) visi, b) misi, c) tujuan, d) sasaran-sasaran, e) strategi, f) kebijakan

\section{SIMPULAN}

Sasaran-sasaran, dari hasil penelitian mengenai dimensi sasaran, obyek wisata ini memang perlu di perhatikan dan dikembangkan oleh Dinas Pariwisata Kabupaten Sukabumi karena potensi alam yang sangat indah dan Obyek Wisata ini perlu lebih di tingkatkan lagi untuk kedepannya seperti akses jalan yang rusak dan sarana dan prasarana yang belum ada di Bumi Perkemahan Cinumpang agar banyak wisatawan yang berkunjung ke Bumi Perkemahan Cinumpang. Kebijakan, kebijakan dari Dinas Pariwisata belum berjalan dengan semestinya. Untuk meningkatkan wisatawan yang berkunjung dan meningkatkan pendapatan asli daerah tentunya harus diikuti dengan sarana dan prasarana yang memadai dan gencarnya promosi yang dilakukan. Namun dalam hal pemasaran pariwisata masih kurang, karena belum adanya fokus dalam promosi Bumi Perkemahan Cinumpang. Rencana-rencana, berdasarkan rencana kinerja sebagimana tertuang dalam Rencana Strategi periode tahun 2018, mengacu pada misi yang telah ditetapkan maka rencana yang akan dicapai atau dihasilkan kurun wisata lima tahun yaitu meningkatkan arus kunjungan wisatawan ke Bumi Perkemahan Cinumpang. Namun hal iu tersebut belum bisa terealisasikan dengan baik. Hal ini dibuktikan dalam pertumbuhan kunjungan wisatawan ke obyek Bumi Perkemahan Cinumpang mengalami penurunan yang signifikan.

\section{DAFTAR PUSTAKA}

Adrian, S. (2009). Implikasi Hukum Atas Sumber Pembiyaan Daerah dalam Kerangka Otonomi Daerah. Jakarta:Sinar Grafika.

Gamal, S. (2004).Dasar-DasarPariwisata.Yogyakarta:Gamal

Diarta, I.K.S. (2009).Pengantar Ilmu Pariwisata, Yogyakarta:Andi

Saladin. (2003). Manajemen Strategi dan Kebijakan Perusahaan. Bandung: Linda Karya

Siahan. (2010). Pajak Daerah dan Retribusi Daerah.a Jakarta:Rajagrafindo. Suwanto 